'protective colouring' to a singularly sensitive and kindly nature.

He edited the Third Book of Thucydides in 1896 and the Sixth in 1905 . From his excellent Introduction to the Third Book a characteristic criticism of the Speeches may be quoted:

Some indeed would claim for the speeches the place of honour. But, well as they may serve the purpose of emphasising any serious political conjuncture, admirably as they reflect

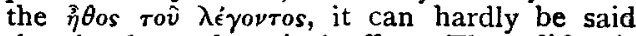
that, in these rhetorical efforts, Thucydides is seen at his best. Those, however, who look for clearness of argument, nervous strength of diction, or incisive power of retort, will find all these and something more - they will find 'writ large' the lesson of democratic brutality, of oligarchic mala fides, of diplomatic shiftiness and over-reaching astuteness.

The services rendered to learning by both these Cambridge scholars, deserve to be retained in grateful remembrance. In the language of the Funeral Oration

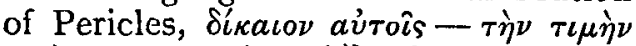

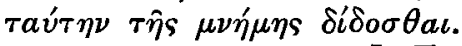

$$
\text { J. E. Sandys. }
$$

\section{ARTHUR LUDWICH.}

ARTHUR LUDWICH, professor of Classical Philology at Königsberg, died on November I2, I920, at the age of 8o. Most of his life was given up to Homer, of whom he was the principal editor in our time, coming between
Jacob la Roche and Mr. Leaf, part of whose material he absorbed. His principal books are the index to Lentz's Herodian (1870), the third edition of Lehrs' Aristarchus (1882), Aristarchs Homerische Textkritik (1884), the Odyssey (1889), the Batrachomyomachia (I896, with an ample commentary), Die homerische Vulgata als voralexandrinische erwiesen (1898), the Iliad (1902); and, outside Homer, Proclus' Hymns (I895), and Nonnus (I909), besides countless articles and Programs. All this he carried out singlehanded. His editions, especially that of the Iliad, are models. He may be called a second Heyne. He had less skill as an emender, or at filling gaps in papyrus. $\mathrm{He}$ was a sound traditional grammarian, successor of Lobeck and Lehrs. Time has vindicated his principles of editing, his conception of the Homeric language, and his exposition of the Alexandrians. The truth of his view of the oldest text of Homer is not so clear.

Professor Ludwich had long and friendly relations with many people in this country. The writer, who met him at Venice in $I 89 I$, received more than one benefit at his hands, and mourns his loss. No one can but feel for an aged scholar whose last days were passed in East Prussia during the war.

T. W. A.

\title{
CORRESPONDENCE
}

\section{PAPYRUS FRAGMENTS OF TYRTAEUS AND OTHERS.}

DEAR SIRS,

May I have space for the correction of a strange statement which appears in a paper of mine in the Classical Review, I919, Vol. XXXIII. p. 9o, and which has just been brought to my notice? The words run: 'Amongst them occur new fragments of an elegiac poem by Tyrtaeus, shown by the writing to be of the third century B.C., dealing with a war against the Gauls.' They should run : 'of an elegiac poem by Tyrtaeus; < and of another elegiac poem > shown by the writing,' etc. The mistake was made when the article was in proof; but I am glad that it did not infect your Index, although it has puzzled one scholar at least.

Yours sincerely, J. U. POWELL.

\section{A CORRECTION.}

IN Classical Revieze Vol. XXXIV., 1920, p. I6I, col. 2 , line I4, the words 'but that the detachment sent by the Ninth was specially large should read 'but evidently the detachment,' etc. The size of the detachment is an inference, not from the Baalbek inscription, but from CIL. XIV. 3612 (previously quoted) and the statement of Tacitus.

J. G. C. ANDERSON.

\section{HYTE MAINAS.}

To the Editors of THE CLASSICAL REVIEW.

DEAR SIRS,

In the last issue of the $C . R .$, Mr. A. J. Hughes complains that in saying júre $\mu a \iota \nu a ́ s$ (Hymn. Dem. 386) means 'like a Maenad' I am hardly fair to Messrs, Allen and Sikes, 